\title{
2018 ALA Midwinter Meeting \& Exhibits
}

The American Library Association (ALA) Midwinter meeting was held in Denver, Colorado from February 9-13, 2018.

ALA is the largest library association in the world, whose mission is to "promote library and librarianship" (ALA Mission \& Priorities ${ }^{1}$ ).

This year, more than 8,000 library and information professionals including librarians, library staff, scholars, educators, publishers, and vendors attended the ALA Midwinter in Denver to present, discuss, share or collaborate on issues of importance in various aspects in the library and information profession.

A lot of sessions were held and various topics were discussed. Topics of highlights this year include new technology, leadership, diversity, access to information and library services, copyright, intellectual freedom, literacy, career development, best practices in a variety of fields of librarianship, evaluation of library impact and library staff development. Library professionals brought up the unfavorable facts of the current environment to the discussion table and call for librarians and other information professionals to seek advocates for libraries and the library profession. Stories about the importance of libraries, librarians and books were told. Some librarians/staff talked about the changes of their roles to make themselves more relevant in the rapidly changing information world. Others shared their experiences and strategies on how they strived to make library collections and resources more accessible to users, carried out programs to connect to the communities and maintain sustainable development. There were also discussions and presentations about efforts made to support diversity, equity and inclusion. For technology and technical services aspects, library professionals discussed some changes and new advances in library technology and how libraries can use the new technology to improve library services. For instances, at some events of Association for Library Collections \& Technical Services (ALCTS), librarians/staff talked about how linked data were practically applied in their libraries, the name reconciliation work and database cleanup projects for their special collections with new technology and tools.

At the Exhibit Hall, more than 450 exhibitors including library vendors, publishers and authors provide the attendees with the opportunities to learn library services, products, tools, technology and new books.

A number of CALA members attended ALA Midwinter and got involved in various activities including making presentations or organizing interest group sessions.

\section{--- Suzhen Chen, University of Hawai'i at Mānoa, HI, USA}

\footnotetext{
1 About ALA. Retrieved March 20, 2018, from http://www.ala.org/aboutala/
} 